\title{
Cassiarins A and B, Novel Antiplasmodial Alkaloids from Cassia siamea
}

Hiroshi Morita, ${ }^{* \dagger}$ Shiori Oshimi, ${ }^{\dagger}$ Yusuke Hirasawa,${ }^{\dagger}$ Koichiro Koyama, ${ }^{\dagger}$ Toshio Honda, ${ }^{\dagger}$ Wiwied Ekasari, Gunawan Indrayanto, and Noor Cholies Zaini ${ }^{\ddagger}$

Facultyl of Pharmaceutical Sciences, Hoshi University, Shinagawa, Tokyo 142-8501, Japan and Faculty of Pharmacy, Airlangga University, Jalan Dharmawangsa Dalam, Surabaya 60286, Indonesia

Supporting Information

Figure S1. $\quad{ }^{1} \mathrm{H}$ NMR spectrum of cassiarin $\mathrm{A}(1)$ in $\mathrm{CDCl}_{3} / \mathrm{CD}_{3} \mathrm{OD}(1: 1)$.

Figure $\mathrm{S} 2 . \quad \quad \quad{ }^{13} \mathrm{C}$ NMR spectrum of cassiarin $\mathrm{A}(1)$ in $\mathrm{CDCl}_{3} / \mathrm{CD}_{3} \mathrm{OD}(1: 1)$.

Figure S3. $\quad{ }^{1} \mathrm{H}^{-1} \mathrm{H}$ COSY spectrum of cassiarin $\mathrm{A}(1)$ in $\mathrm{CDCl}_{3} / \mathrm{CD}_{3} \mathrm{OD}(1: 1)$.

Figure S4. NOESY spectrum of cassiarin A (1) in $\mathrm{CDCl}_{3} / \mathrm{CD}_{3} \mathrm{OD}(1: 1)$.

Figure S5. $\quad \mathrm{HMQC}$ spectrum of cassiarin $\mathrm{A}(1)$ in $\mathrm{CDCl}_{3} / \mathrm{CD}_{3} \mathrm{OD}(1: 1)$.

Figure S6. $\quad \mathrm{HMBC}$ spectrum of cassiarin $\mathrm{A}(1)$ in $\mathrm{CDCl}_{3} / \mathrm{CD}_{3} \mathrm{OD}(1: 1)$.

Figure S7. $\quad{ }^{1} \mathrm{H}$ NMR spectrum of cassiarin $\mathrm{B}(2)$ in $\mathrm{CDCl}_{3} / \mathrm{CD}_{3} \mathrm{OD}(1: 1)$.

Figure S8. $\quad{ }^{13} \mathrm{C}$ NMR spectrum of cassiarin $\mathrm{B}(2)$ in $\mathrm{CDCl}_{3} / \mathrm{CD}_{3} \mathrm{OD}(1: 1)$.

Figure S9. $\quad{ }^{1} \mathrm{H}^{-1} \mathrm{H}$ COSY spectrum of cassiarin $\mathrm{B}(2)$ in $\mathrm{CDCl}_{3} / \mathrm{CD}_{3} \mathrm{OD}(1: 1)$.

Figure S10. NOESY spectrum of cassiarin B (2) in $\mathrm{CDCl}_{3} / \mathrm{CD}_{3} \mathrm{OD}(1: 1)$.

Figure S11. HMQC spectrum of cassiarin $\mathrm{B}(2)$ in $\mathrm{CDCl}_{3} / \mathrm{CD}_{3} \mathrm{OD}(1: 1)$.

Figure S12. $\mathrm{HMBC}$ spectrum of cassiarin $\mathrm{B}(2)$ in $\mathrm{CDCl}_{3} / \mathrm{CD}_{3} \mathrm{OD}(1: 1)$. 


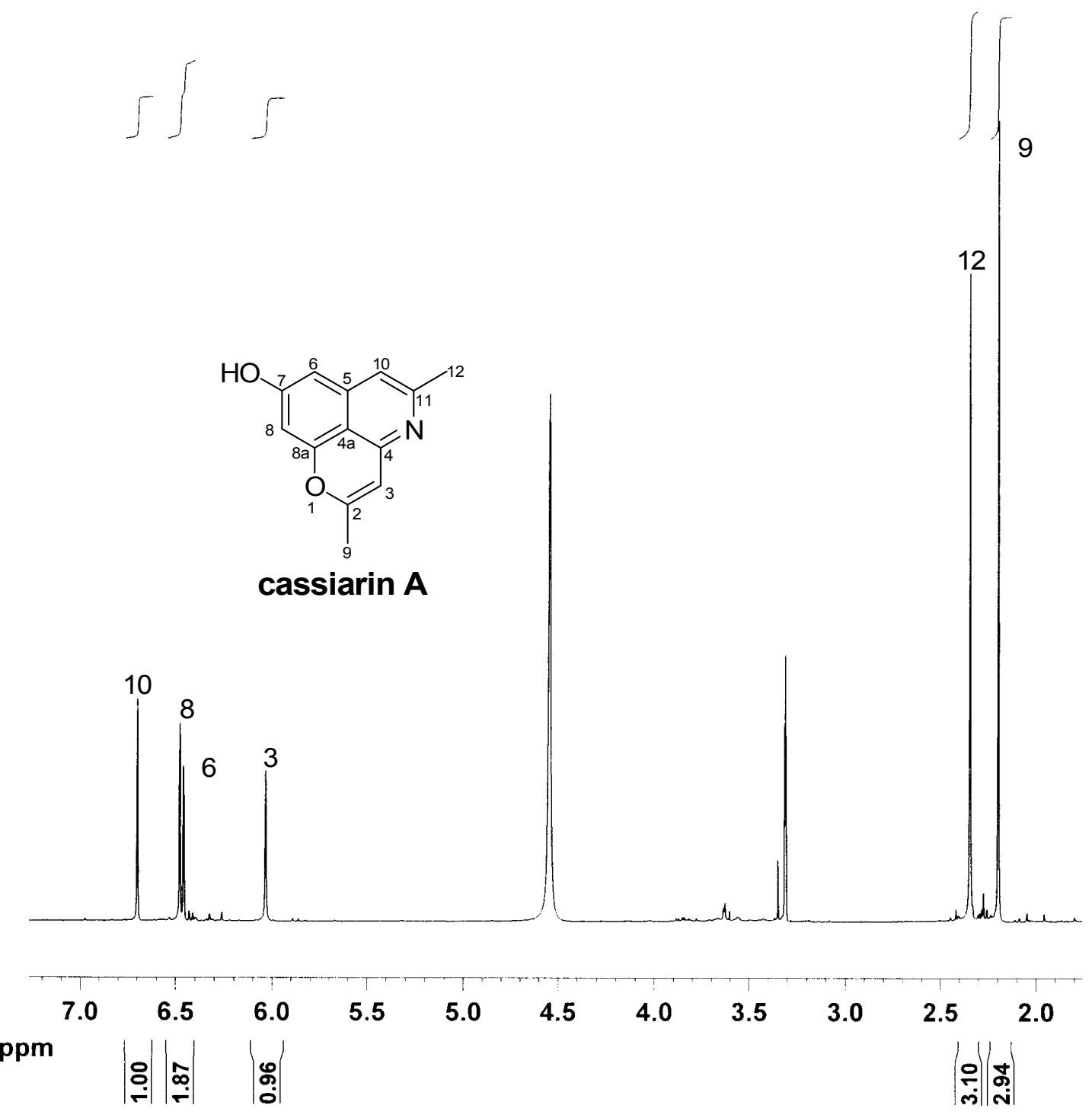

Figure S1. $\quad{ }_{1} \mathrm{H}$ NMR spectrum of cassiarin $\mathrm{A}(\mathbf{1})$ in $\mathrm{CDCl}_{3} / \mathrm{CD}_{3} \mathrm{OD}(1: 1)$. 


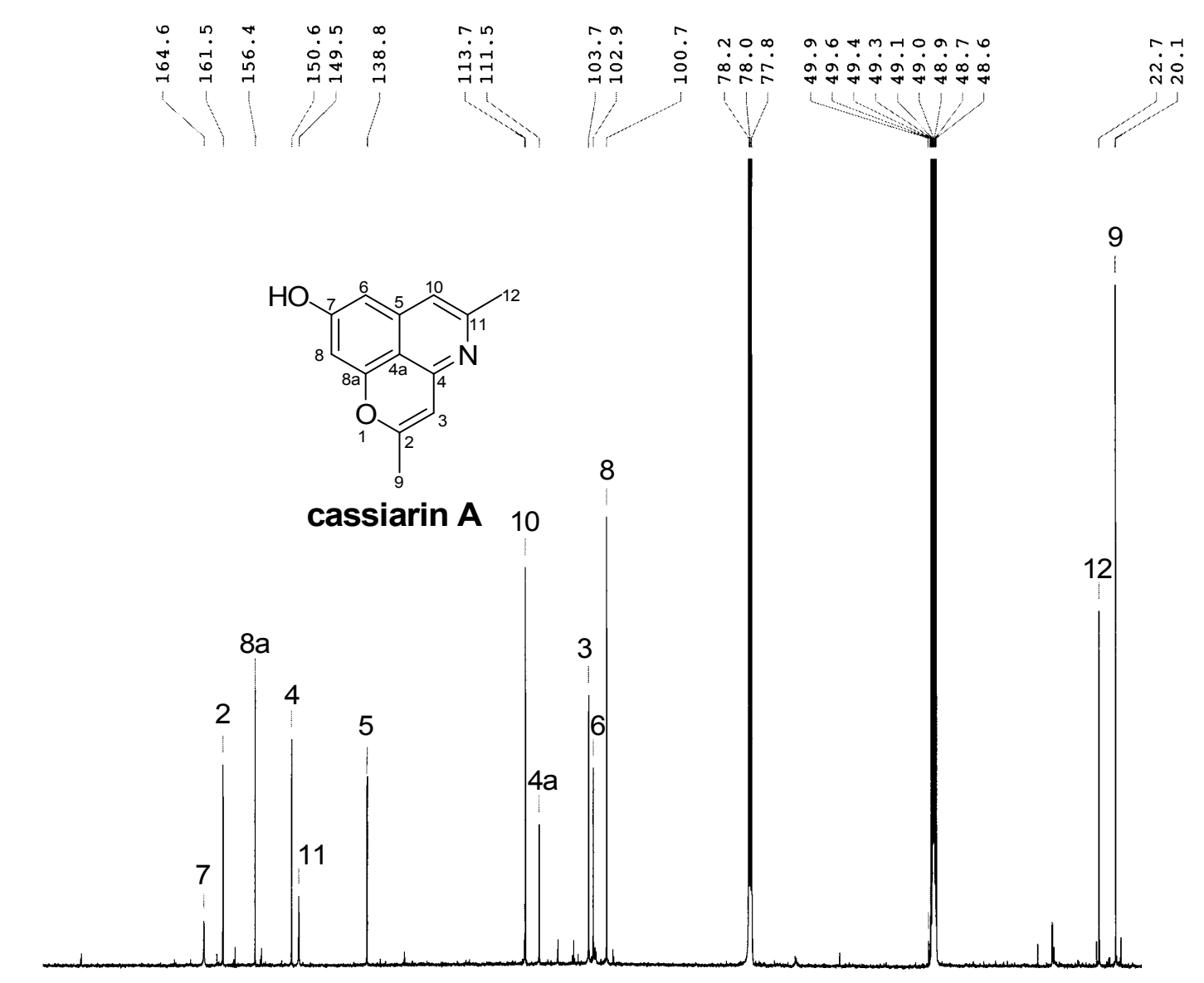

$\begin{array}{llllllllllllllllll}\text { ppm } & 180 & 170 & 160 & 150 & 140 & 130 & 120 & 110 & 100 & 90 & 80 & 70 & 60 & 50 & 40 & 30 & 20\end{array}$

Figure S2. $\quad{ }^{13} \mathrm{C}$ NMR spectrum of cassiarin $\mathrm{A}(1)$ in $\mathrm{CDCl}_{3} / \mathrm{CD}_{3} \mathrm{OD}(1: 1)$. 


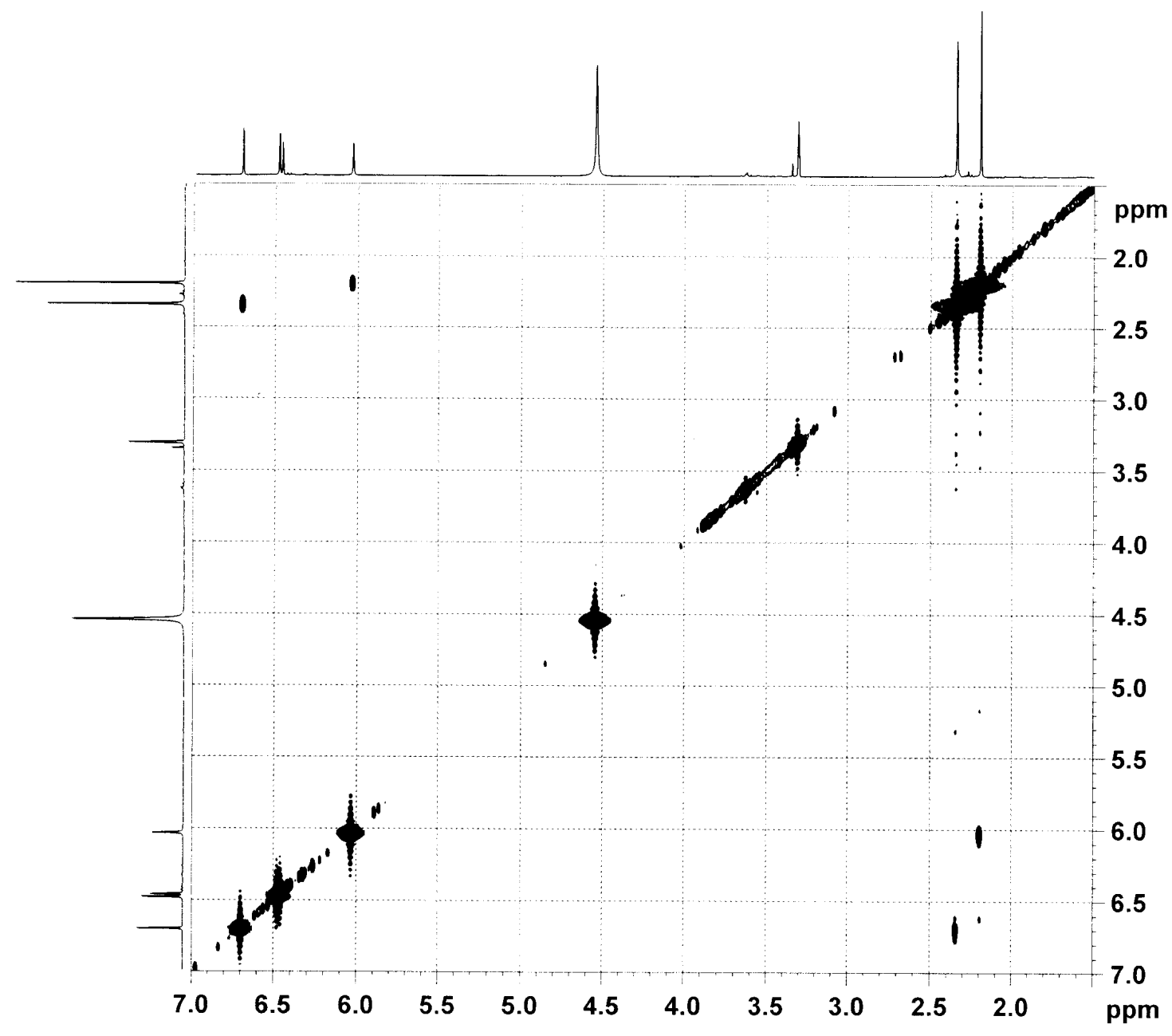

Figure S3. $\quad{ }^{1} \mathrm{H}^{-1} \mathrm{H}$ COSY spectrum of cassiarin A (1) in $\mathrm{CDCl}_{3} / \mathrm{CD}_{3} \mathrm{OD}(1: 1)$. 


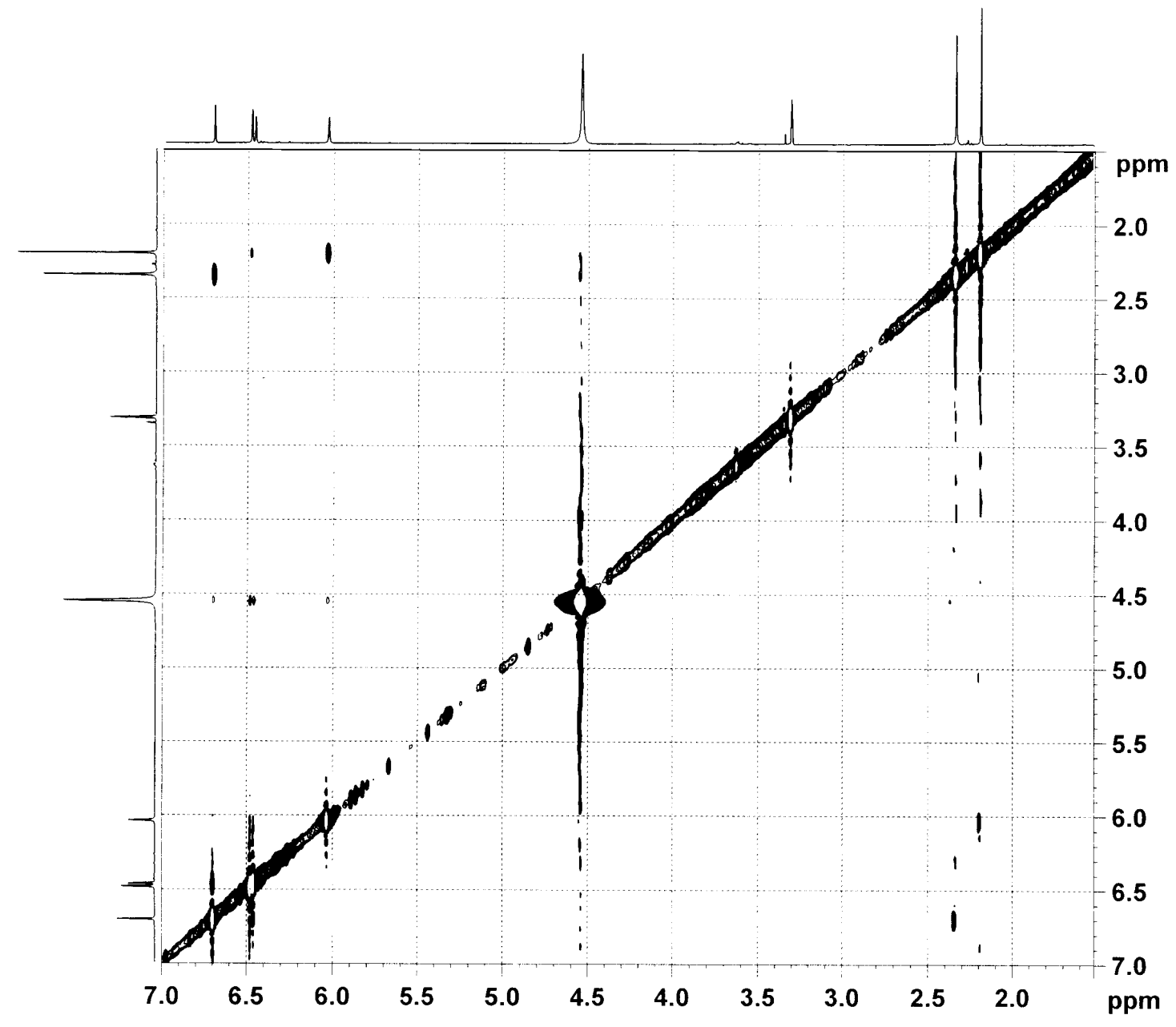

Figure S4. NOESY spectrum of cassiarin A (1) in $\mathrm{CDCl}_{3} / \mathrm{CD}_{3} \mathrm{OD}(1: 1)$. 


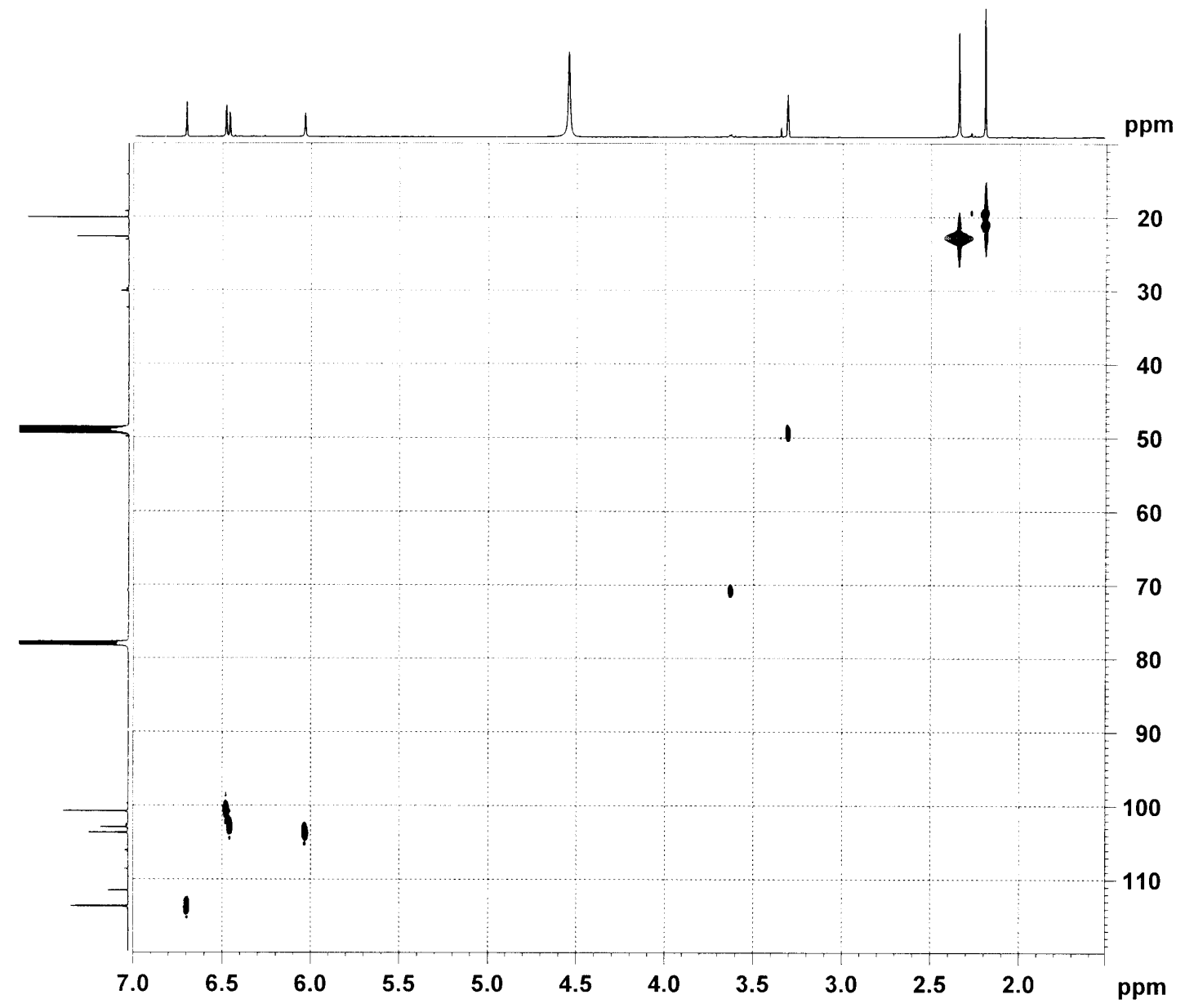

Figure S5. HMQC spectrum of cassiarin $\mathrm{A}(1)$ in $\mathrm{CDCl}_{3} / \mathrm{CD}_{3} \mathrm{OD}(1: 1)$. 


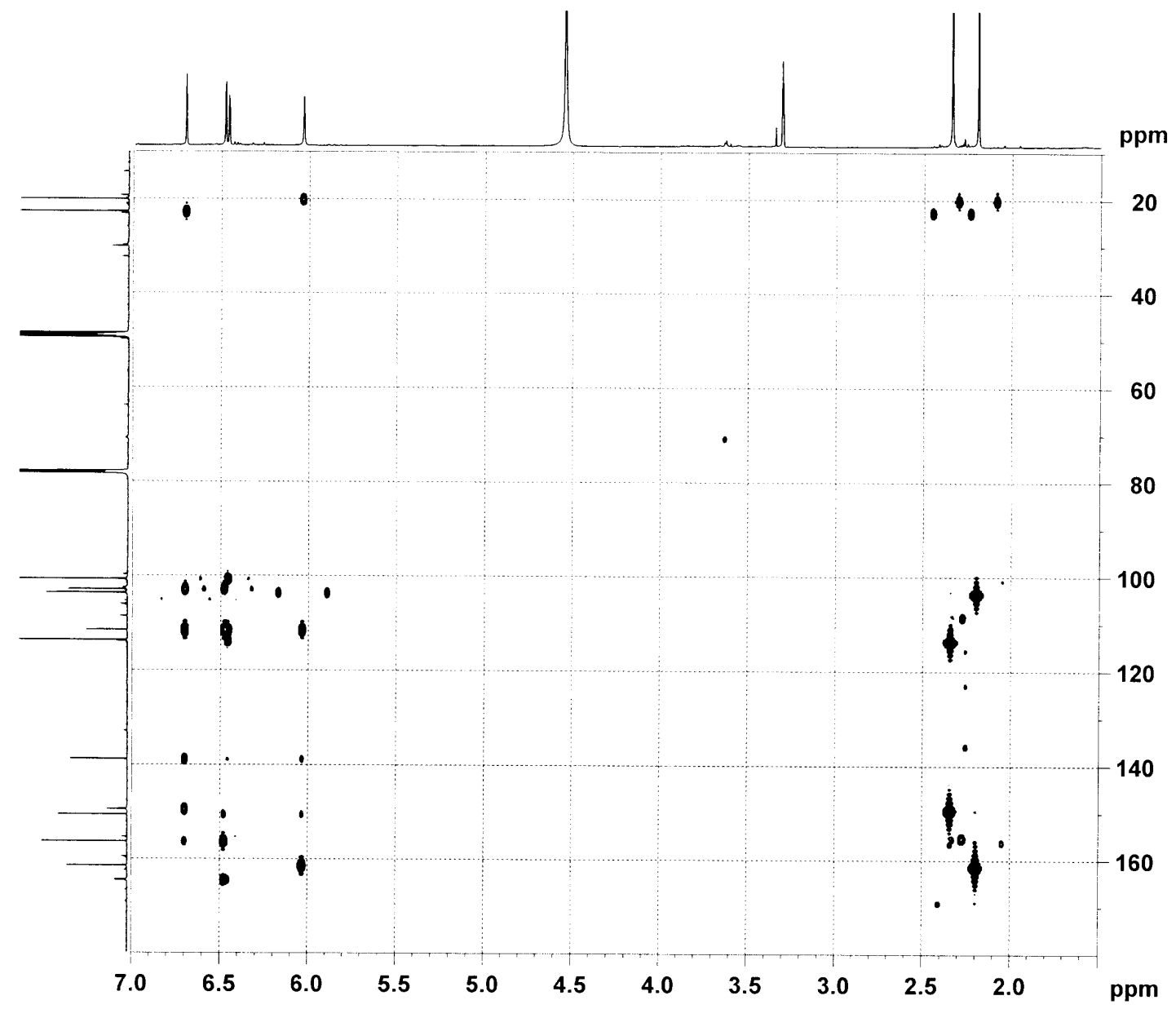

Figure S6. $\quad \mathrm{HMBC}$ spectrum of cassiarin $\mathrm{A}(1)$ in $\mathrm{CDCl}_{3} / \mathrm{CD}_{3} \mathrm{OD}(1: 1)$. 


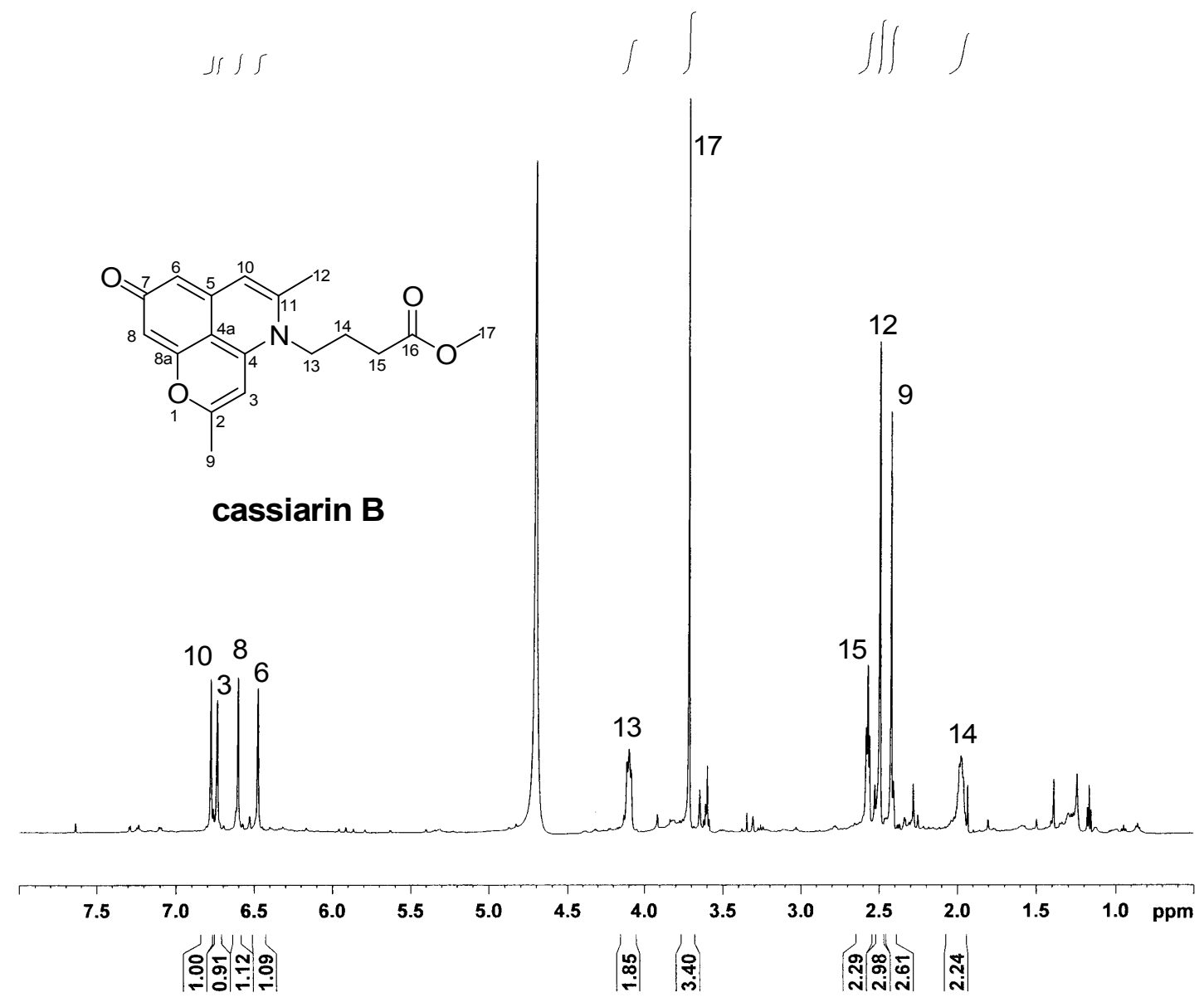

Figure S7. $\quad{ }_{1} \mathrm{H}$ NMR spectrum of cassiarin B (2) in $\mathrm{CDCl}_{3} / \mathrm{CD}_{3} \mathrm{OD}(1: 1)$. 


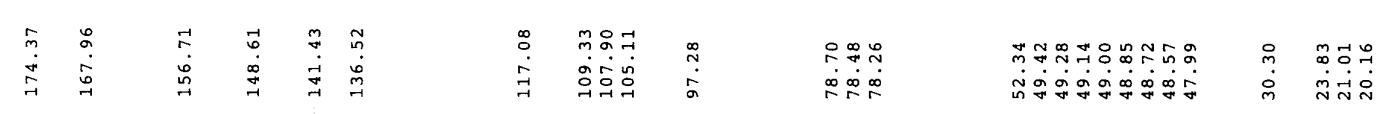

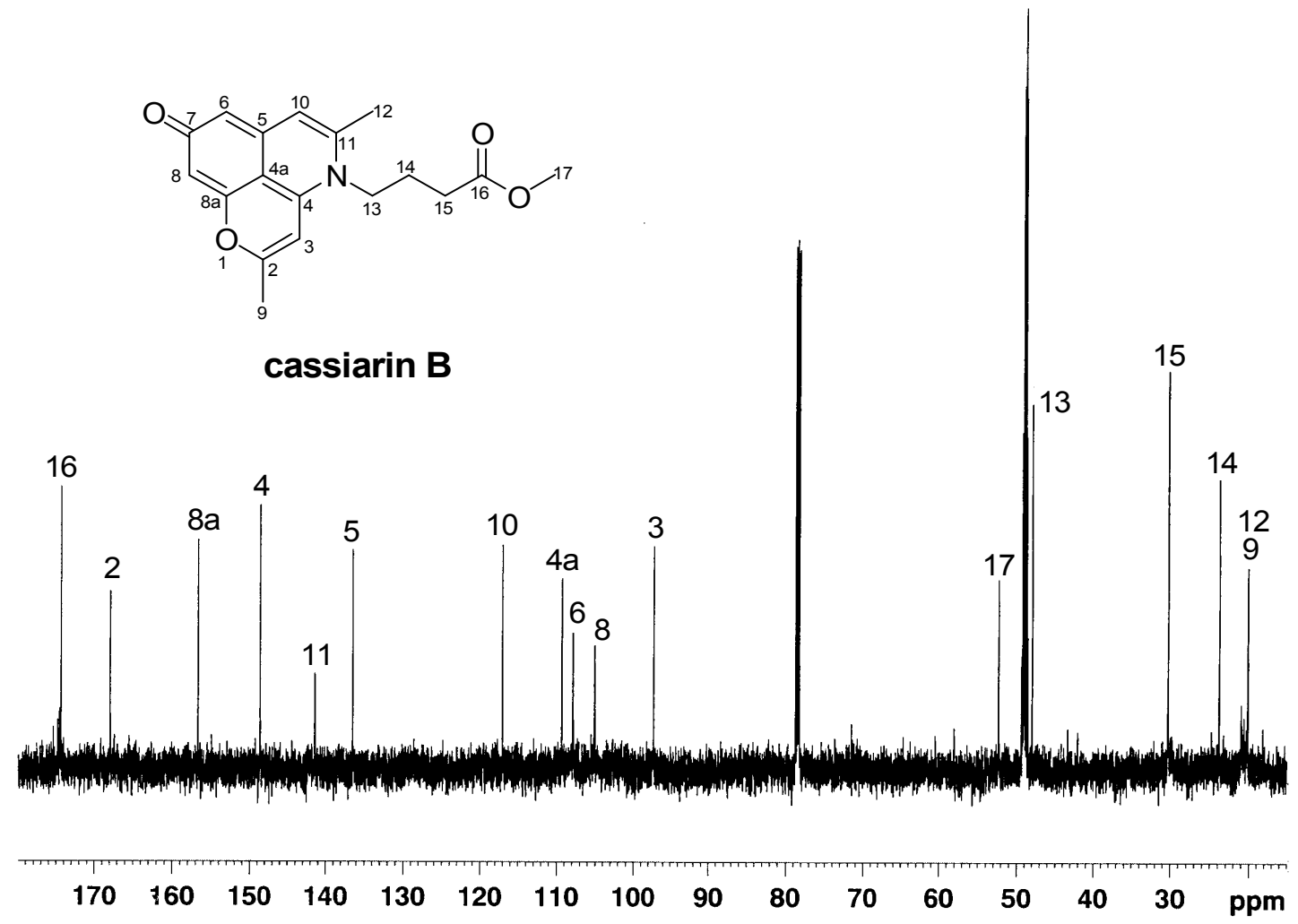

Figure S8. $\quad{ }^{13} \mathrm{C}$ NMR spectrum of cassiarin $\mathrm{B}(2)$ in $\mathrm{CDCl}_{3} / \mathrm{CD}_{3} \mathrm{OD}(1: 1)$. 


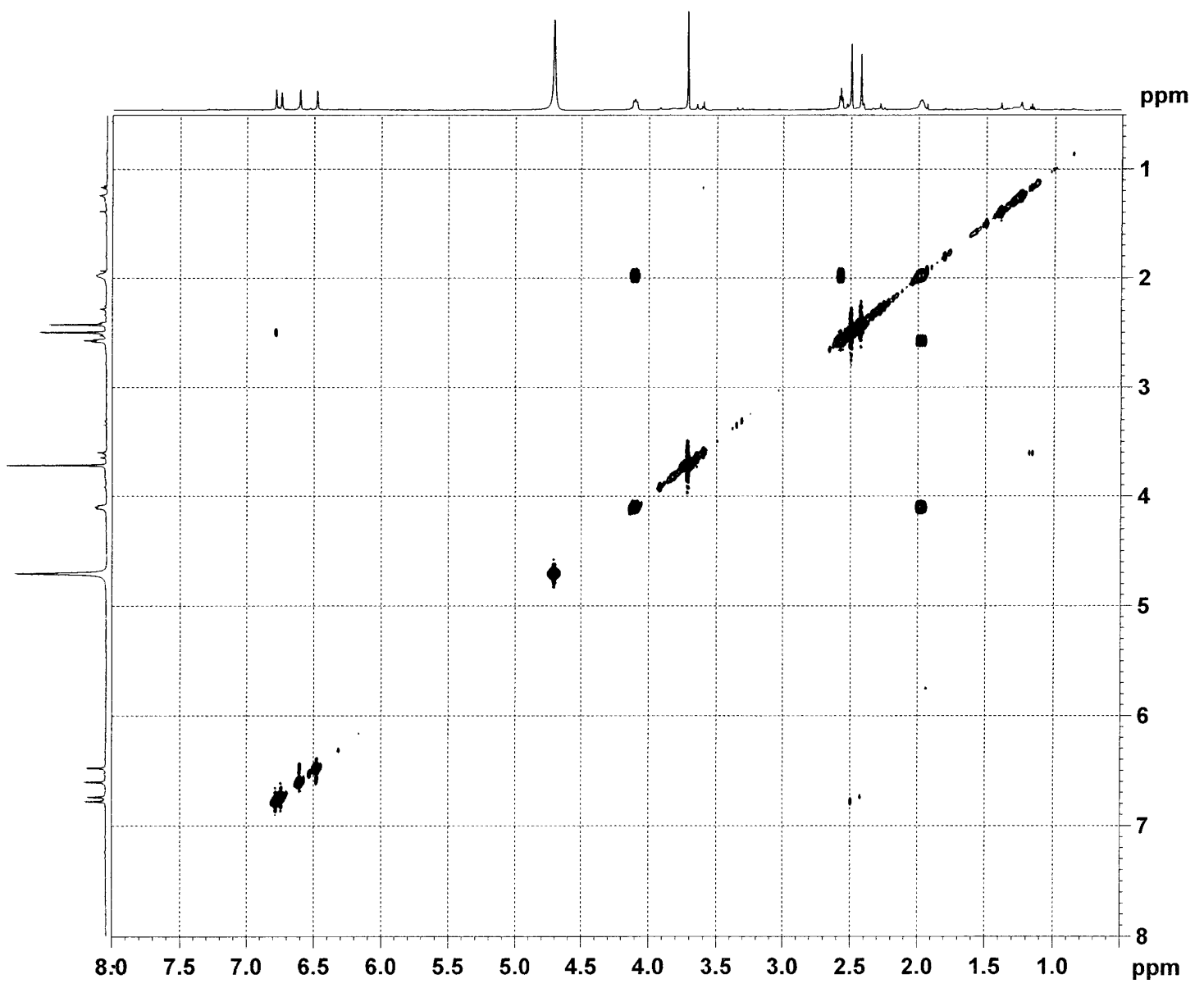

Figure S9. $\quad{ }^{1} \mathrm{H}^{-1} \mathrm{H}$ COSY spectrum of cassiarin $\mathrm{B}(2)$ in $\mathrm{CDCl}_{3} / \mathrm{CD}_{3} \mathrm{OD}(1: 1)$. S10 


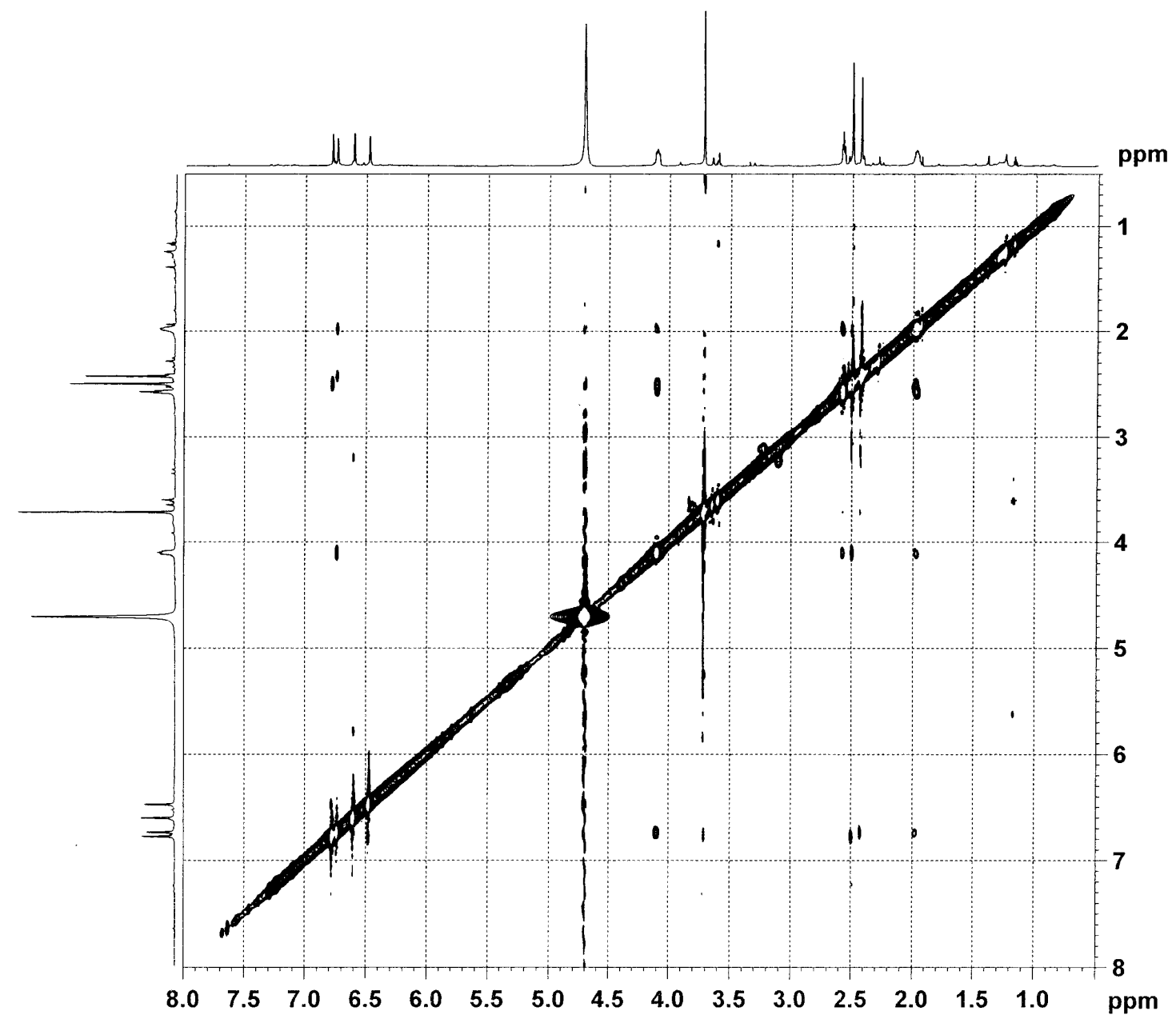

Figure S10. NOESY spectrum of cassiarin B (2) in $\mathrm{CDCl}_{3} / \mathrm{CD}_{3} \mathrm{OD}(1: 1)$. 


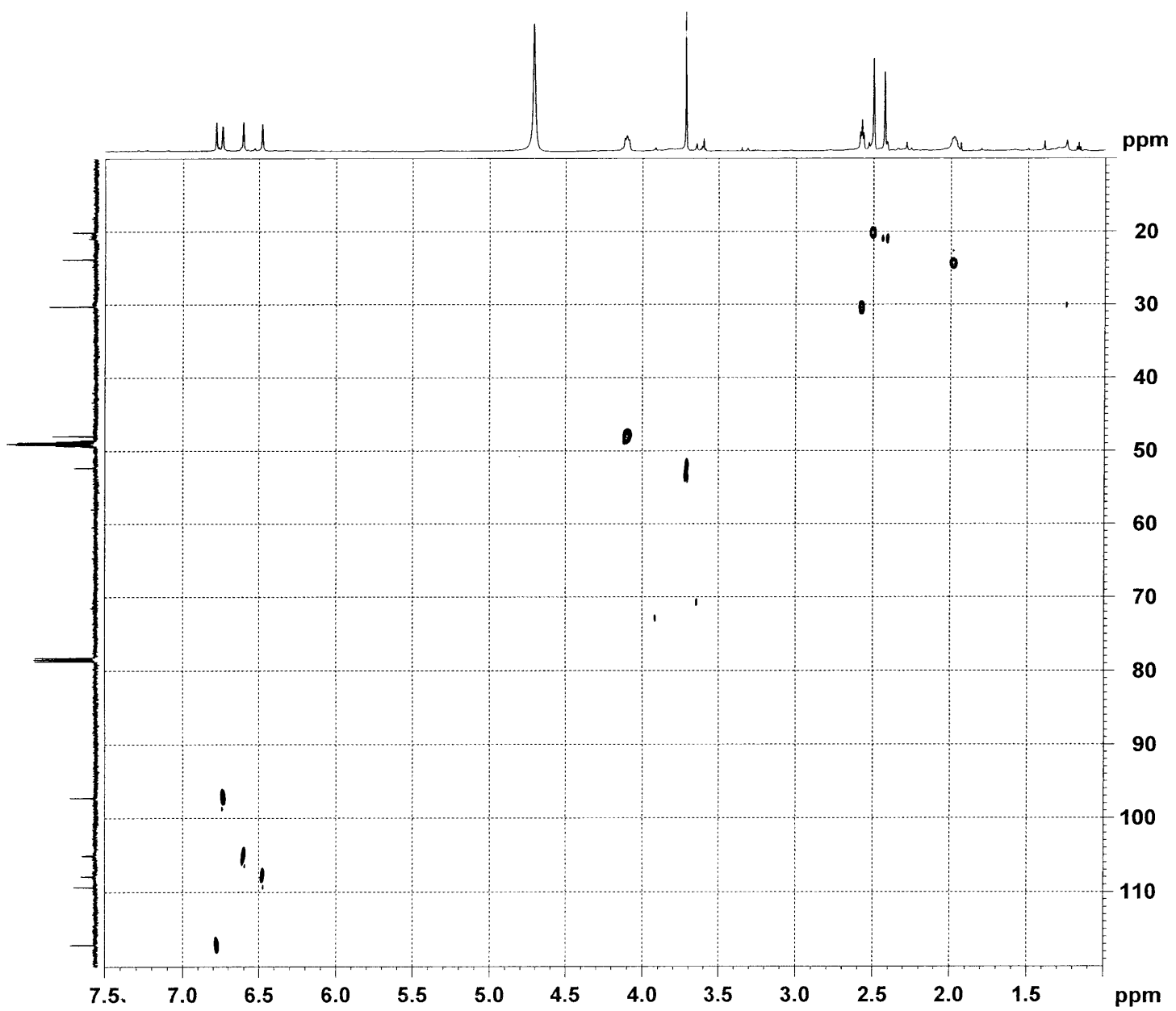

Figure S11. HMQC spectrum of cassiarin $\mathrm{B}(2)$ in $\mathrm{CDCl}_{3} / \mathrm{CD}_{3} \mathrm{OD}(1: 1)$.

$$
\mathrm{S} 12
$$




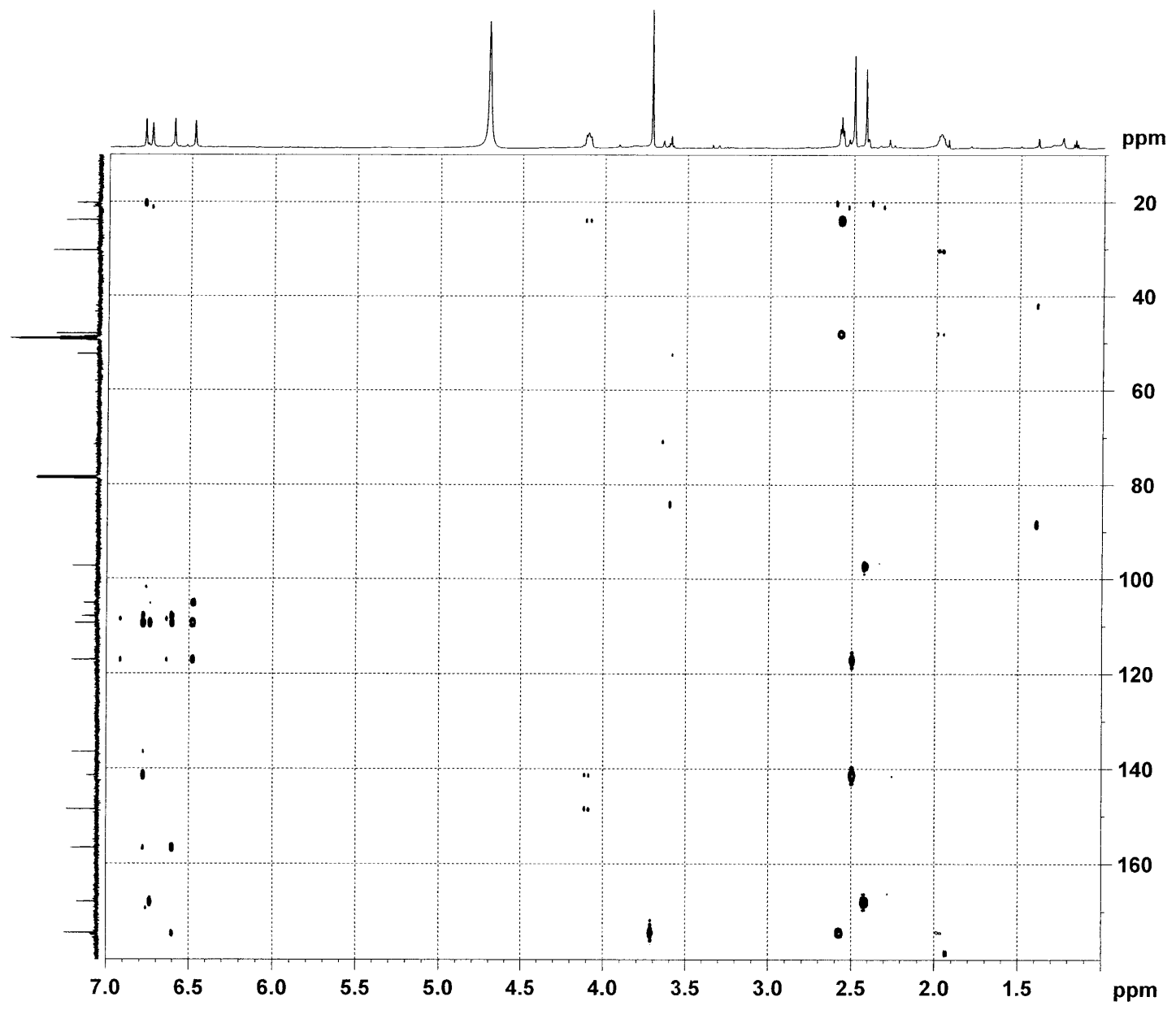

Figure S12. $\quad \mathrm{HMBC}$ spectrum of cassiarin $\mathrm{B}(2)$ in $\mathrm{CDCl}_{3} / \mathrm{CD}_{3} \mathrm{OD}(1: 1)$. S13 